\title{
Analysis of Interests and Mathematical Talents of Prospective Students in the Department of Mathematics Education at Universitas Pendidikan Muhammadiyah Sorong Based on Multiple Intelligences
}

\author{
$1^{\text {st }}$ Suhartini Sumadi ${ }^{1}, 2^{\text {nd }}$ Teguh Yuliandri Putra ${ }^{2}, 3^{\text {rd }}$ Istiqomah $^{3}$ \\ \{suhartini.sumadi@gmail.com ${ }^{1}$, teguhputra043@gmail.com ${ }^{2}$, annieistiqomah@gmail.com ${ }^{3}$ \} \\ Universitas Pendidikan Muhammadiyah Sorong, 081217944471 ${ }^{1}$, Universitas Pendidikan \\ Muhammadiyah Sorong, 082198993391², Universitas Pendidikan Muhammadiyah Sorong, \\ $081225560735^{3}$
}

\begin{abstract}
The aim from this research is to describe: 1) multiple intelligence of prospective students in the Department of Mathematics Education at Universitas Pendidikan Muhammadiyah Sorong; 2) interest in prospective students in the Department of Mathematics Education at Universitas Pendidikan Muhammadiyah Sorong based on multiple intelligences.; 3) interests and talents of prospective students in the Department of Mathematics Education at Universitas Pendidikan Muhammadiyah Sorong based on multiple intelligences. The approach used is a qualitative and quantitative approach. The results of this study are 1) the domain of dominant intelligence in prospective students namely introspective, interactive and analytical; 2) interest criteria with introspective and interactive domains include medium criteria and high criteria, while analytic includes high criteria; 3 ) talent in solving problems with the analytical and introspective domains and interactively (especially interests with high criteria) has been carried out as a whole according to the Polya stage, while the interactive domain of interests with medium criteria, is not done as a whole
\end{abstract}

Keyword: interest, talent in mathematics, multiple intelligences, problem solving

\section{Introduction}

A problem is a situation faced by someone, and requires a solution, and the way to get a solution is not immediately known (Posamentier \& Krulik, 1988). If a problem is given to someone to determine their talents and interests. So, a situation is said to be a problem depending on someone who faces the problem depending on the type of intelligence.

Intelligence is a concept of the general ability of every person to adjust to his environment. These general abilities, in which there are very specific abilities. These specific abilities in each person are given a condition that enables the achievement of certain knowledge, skills, or skills after going through an exercise. This is called Talent. Because an intelligence test is not designed to reveal these three special abilities, so talent cannot be immediately known through intelligence tests. 
The development of one's intelligence can be determined, one of which is the accuracy of someone (student) in choosing a department when in college. The world of lectures is the highest level for someone gets knowledge. Whole cross science in the university world have their own uniqueness and characteristics, in terms of material and learning models. At the core of this, students are able to improve their abilities, when they choose the proper department. The fact is that candidates often get it, new students wrongly take their scientific majors because of several factors. One of them, his inability to measure the level of intelligence.

Basically, each prospective student is someone who is in the interchange period (pre-adult to adult). This situation often makes prospective students feel confused in the benchmark defining interest in talent and level of intelligence. In general, humans have multiple intelligences.

Intelligence is a very important thing in the world of education (Prawira, 2011). Multiple intelligence according to Gardner (2003) means that the ability to solve problems, or create valuable products in a cultural environment of society. This is what will trigger the ability of prospective students to adapt in various situations and can be abstracted on a quality that is the same in all cross of department, one of which is a department of mathematics education.

Department of mathematics education is one of the department in the Teacher Training and Education Faculty. What is the difference between the Department of Mathematics Education and the Pure Mathematics study program at the MIPA Faculty? The difference is in educational science courses which are only obtained in the Department of Mathematics Education. This department learns the basics of mathematical sciences such as algebra, geometry, calculus, statistics, and trigonometry, accompanied by the science of education such as educational theories which include methods of mathematics learning, teaching planning, and teaching evaluation, also the basics of science science will be studied others such as physics, biology, and chemistry. Same is the case with departments on other educational science groups.

The description, the measurement of multiple intelligences in prospective students of mathematics education study programs becomes a benchmark for new students to adapt to various matters relating to the product. The urgency of this research is how to get a specific picture of the initial ability of prospective students before the student carries out the lecture process. This condition shows that of course there are interesting facts to look for data and know the early development of the plural intelligence level of prospective students who choose department of mathematics education at Universitas Pendidikan Muhammadiyah (UNIMUDA) Sorong, which is carried out with several forms of tests that are adapted and collect all forms of intelligence plural new student candidates.

Based on the explanation so the formulation of the problem in this study, yaitu: 1) What are the forms of multiple intelligences for prospective students in the department of mathematics education at Universitas Pendidikan Muhammadiyah Sorong?; 2) How is the relationship between multiple intelligences and the interests of prospective students in the department of mathematics education at Universitas Pendidikan Muhammadiyah Sorong?; 3) How is the relationship between multiple intelligences and talent interests of prospective students in the department of mathematics education at Universitas Pendidikan Muhammadiyah Sorong? 


\section{Research methods}

This research was designed to describe and explore the process of solving students' mathematical problems based on their multiple intelligences. Therefore, the type of research used in this study is descriptive exploratory, and the approach used is a qualitative and quantitative approach.

Subjects in the study were prospective students of the department of mathematics education FKIP Universitas Pendidikan Muhammadiyah Sorong which is 16 people. The instrument used in this study is the Test of Multiple Intelligences (Yaumi, M. \& Ibrahim, N., 2013) and questionnaires of interest in mathematics (Slameto, 2010). The data in this study were analyzed by reducing data, presenting data and drawing conclusions.

\section{Result and Discussion}

\subsection{Research Result}

The results of this study are grouped according to the dominant intelligence possessed. The domains of multiple intelligences in this study are grouped into three domains (Yaumi, M. \& Ibrahim, N., 2013), that is: 1) interactive domains include verbal, interpersonal and kinesthetic intelligence; 2) analytical domain which includes musical intelligence, logic and naturalistic intelligence; 3 ) introspective domain consisting of existential, intrapersonal, and visual intelligence.

Table 1. Frequency of Results of Multiple Intelligence Tests

\begin{tabular}{lll}
\hline Multiple Intelligence Domain & Frequency & Percentage (\%) \\
\hline Interactive & 7 & 43.8 \\
Analytic & 2 & 12.5 \\
Introspektif & 8 & 50 \\
\hline
\end{tabular}

Table 1 shows that 16 prospective students of department of mathematics education have multiple intelligence domains which are dominant in the introspective domain of 8 people $(50 \%)$. While the domain that is dominant in the analytic domain is 2 people $(12.5 \%)$ and the introspective domain is 7 people $(43.8 \%)$. The results of the multiple intelligence test show that there is one subject that has the dominant domain of interactive and analytical as well.

\subsubsection{Interest in Mathematics Based on Multiple Intelligence}

The results of the questionnaire of interest in mathematics based on three dominant intelligences, can be presented as follows.

\subsubsection{Interactive Domain}

The results of the questionnaire interest in mathematics which have an interactive domain consisting of verbal Intelligence, interpersonal and kinesthetic intelligence are shown in table 2.

Table 2. Interest in Mathematics Based on Interactive Domains

\begin{tabular}{llll}
\hline Subject & Average & Percentage (\%) & Criteria \\
\hline C & 3.17 & 79.17 & High \\
D & 3.4 & 93.75 & High \\
G & 3 & 75 & medium
\end{tabular}




\begin{tabular}{llll}
$\mathbf{H}$ & 3.04 & 76.04 & High \\
$\mathbf{M}$ & 2.92 & 72.92 & medium \\
$\mathbf{O}$ & 2.92 & 72.92 & medium \\
$\mathbf{P}$ & 3.46 & 86.46 & High \\
\hline
\end{tabular}

Table 2 shows that subjects have interactive domains with two criteria, namely high and medium criteria. Subjects with high criteria were four people, namely at the percentage of $79.17 \%, 93.75 \%, 76.04 \%$ and $86.46 \%$. while interest with medium criteria is three people.

\subsubsection{Analytical Domain}

The results of the questionnaire interest in mathematics that has an analytic domain consisting of musical, logical and naturalistic intelligence are shown in table 3.

Table 3. Interest in Mathematics Based on Analytical Domains

\begin{tabular}{llll}
\hline Subject & Average & Percentage (\%) & Criteria \\
\hline $\mathbf{C}$ & 3.17 & 79.17 & High \\
$\mathbf{E}$ & 3.4 & 85.42 & High \\
\hline
\end{tabular}

Table 2 shows that there are 2 people who have high criteria with a percentage of $79.17 \%$ and $85.42 \%$.

\subsubsection{Introspective Domain}

The results of the questionnaire interest in mathematics that have an introspective domain consisting of existential, intrapersonal, and visual intelligence are shown in table 4 .

Table 4. Interest in Mathematics Based on Introspective Domains

\begin{tabular}{llll}
\hline Subject & Average & Percentage (\%) & Criteria \\
\hline A & 2.33 & 58.33 & medium \\
B & 3.25 & 81.25 & High \\
F & 3.52 & 84.38 & High \\
I & 2.46 & 61.46 & medium \\
J & 3.04 & 76.04 & High \\
K & 3.42 & 85.42 & High \\
L & 3.13 & 78.13 & High \\
$\mathbf{N}$ & 3.33 & 83.33 & High \\
\hline
\end{tabular}

Table 2 shows that subjects who have an introspective domain with two criteria, namely high and medium criteria. Subjects with high criteria are as many as six people, namely at the percentage of $81.25 \%, 84.38 \%, 76.04 \%, 85.42 \%, 78.13 \%$ and $83.33 \%$, while interests with moderate criteria are as many as two.

\subsubsection{Interest and Talent Based on Compound Intelligence}

A person's talent in this study is seen from the way to solve problems according to the stages of Polya (1973). The results of mathematical problem solving to show talent based on three dominant intelligences, can be described as follows.

\subsubsection{Stage of Understanding the Problem}

This stage, someone is able to identify the problem of a problem, namely by understanding the problem correctly. The problem solving test results from subjects that match the criteria of interest and multiple intelligence domains that are dominant at the stage of understanding the problem can be presented as follows.

a. Interactive Domain

The results of problem solving tests at this stage are divided into two according to the criteria of interest obtained. Based on the results of the test, the stage of understanding 
the problem in interest with both of these criteria, the subject writes what has been understood by writing what is known in the problem solving process.

b. Analytical Domain

The results of problem solving tests at this stage, the subject writes what has been understood by writing what is known in the problem solving process.

c. Introspective Domain

The results of problem solving tests at this stage are divided into two according to the criteria of interest obtained. Based on the results of the test, the stage of understanding the problem in interest with the criteria is being, the subject writes what has been understood by writing what is known in the problem solving process. These results are the same as the problem solving process at this stage in subjects who have high criteria of interest.

\subsubsection{Stage of devise a plan}

This stage shows that the subject is able to plan problem solving by compiling and restating the problem by using reasoning, variables and equations, using formulas or traits of numbers, trying to simplify problems and using known information to develop new information.

The problem solving test results from subjects that match the interest criteria and multiple intelligence domains that are dominant in the planning stage can be presented as follows.

a. Interactive Domain

Subjects with this domain, have gone through the planning stage. Preparation of plans on subjects with criteria of interest being worked out by writing the formula first to solve the problem, while in subjects with high criteria written information on each step of solving the problem.

b. Analytical Domain

Subjects with this domain, have gone through the planning stage. The subject knows what is at issue with the problem by writing it on the results of the subject with this domain, has gone through the planning stage. The subject knows what is at issue with the problem by writing it on the results.

c. Introspective Domain

Subjects with this domain, have gone through the planning stage. However, the preparation of plans on subjects with moderate interest criteria is not compiled in detail, while in subjects with high criteria have been written in detail, namely writing information on each step of solving the problem.

\subsubsection{Stage of Implementing the Plan}

This stage shows that someone is able to solve a problem in accordance with the plan that has been written. The problem solving test results from subjects that match the interest criteria and multiple intelligence domains that are dominant at the stage of implementing the plan can be presented as follows.

a. Interactive Domain

Hasil penelitian menunjukkan bahwa subjek dengan domain ini telah melakukan tahap ini sesuai dengan rencana. Subjek dengan kriteria minat tinggi telah memecahkan masalah dengan runtun sesuai langkah-langkah yang dituliskan hingga memperoleh hasil. Subjek dengan kriteria minat sedang, melakukan tahap ini dengan menyelesaikan masalah sesuai dengan langkah pada rumus yang ditulis.

b. Analytical Domain 
Hasil penelitian menunjukkan bahwa subjek dengan domain ini telah melakukan tahap ini sesuai dengan rencana. Subjek telah memecahkan masalah dengan runtun hingga memperoleh hasil.

c. Introspective Domain

The results of the study indicate that the subject with this domain has carried out this stage according to the plan. Subjects with high interest criteria have solved the problem in order until they get results. However, subjects with interest criteria were solving problems from two different questions with one solution.

\subsubsection{Stage of looking back}

This stage is shown by students checking back the results obtained, by checking all the things that have been completed. The problem solving test results from subjects that match the interest criteria and multiple intelligence domains that are dominant at stage of looking back can be presented as follows.

a. Interactive Domain

Subjects in this domain have done this stage, namely by proving the problem solving process to ensure the solution has been obtained.

b. Analytical Domain

Subjects in this domain have done this stage, namely by writing conclusions from the problem being resolved.

c. Introspective Domain

Subjects with high interest criteria in this domain have done this stage, namely by proving the problem solving process to ensure the solution has been obtained. While subjects with moderate interest criteria did not do this stage because the solutions obtained were not resolved in detail and were not proven.

The explanation shows that, the domain of multiple intelligences from different subjects. The subject's interest in mathematics includes medium and high criteria. The steps to solve the problem according to Polya and the interest viewed from the multiple intelligence domains indicate that the way the problem is solved is also different.

Interactive Domain, the interest of subjects who have an interactive dominant intelligence domain is divided into two criteria, namely medium and high criteria. The subject carried out Polya's problem solving steps as a whole. How to understand the problem has been explained things that are known to the problem. The process of preparing and implementing the plan is done by writing down the formulas and steps. The rechecking phase is done by proof.

Analytical Domain, subjects with this intelligence domain have an interest in high criteria. The subject carried out Polya's problem solving steps as a whole. How to understand the problem has been explained things that are known to the problem. The process of preparing and implementing the plan is done by writing down the formulas and steps. The rechecking phase is done by proof.

Interactive Domain, subjects with subjects with this intelligence domain have interests in high and medium criteria. Subjects with moderate interest criteria, carrying out Polya's problem solving steps were not as a whole. The stage of understanding the problem is done, but not clearly, the stages of preparation and implementation of the plan have been carried out. Subjects with high interest criteria carry out Polya problem solving steps as a whole. How to understand the problem has been explained things that are known to the problem. The process of preparing and implementing the plan is done by writing down the formulas and steps. The rechecking phase is done by proof. 
Based on these explanations, the problem solving process with the polya stage by subjects who have the domain of dominant intelligence and interest in mathematics, is shown in Figure 1.

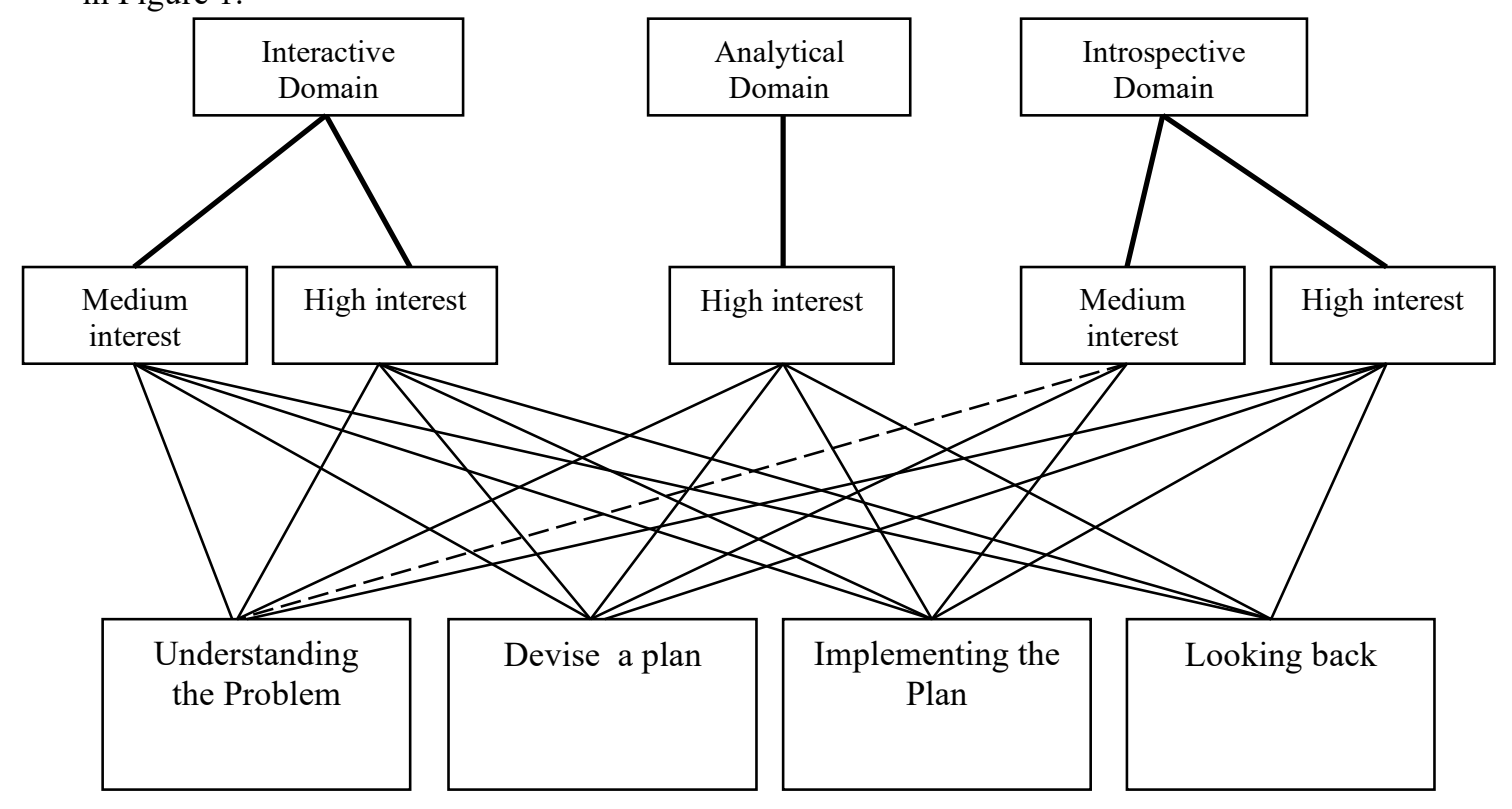

Figure 1. The process of problem solving and interest in mathematics in terms of multiple intelligences

\subsection{Discussion}

The presentation of the problem solving process shows that everyone has a similar process of solving. But there are still some people who have difficulty in solving mathematical problems (In'am, 2015). Problem solving can be improved by paying attention to one's multiple intelligence (Rahbarnia, etc., 2014). There are several people whose problem solving is written incompletely. Accordance with previous research In'am (2015) states that one of the difficulties students have in solving mathematical problems is mistakes in writing or counting.

The results of the research that have been explained show that the interest of prospective new students in the mathematics education study program with different intelligence domains in each person having an interest in mathematics is included in the medium and high criteria. Previous research states that the steps to solve a mathematical problem is different in some people who have different multiple intelligences (Rohmatin \& Rahmawati, 2013; Sumadi, 2016; Wijaya \& Sudarmin, 2016). The process of solving problems with moderate interest criteria is different from the high interest criteria. In accordance with previous research that people with moderate and high interest criteria solve problems with all the steps of Polya, but in the moderate interest criteria there are still steps to solve Polya's problems that are still incomplete (Darojat \& Kartono, 2016; Sapitri, dkk, 2019).

\section{Conclusions}

Based on the results of data analysis that has been presented, it can be concluded that: 
1) Prospective students of mathematics education study programs have the most dominant intelligence domains, namely the introspective domain that includes existential, intrapersonal, and visual intelligence, followed by an interactive domain that includes verbal, interpersonal and kinesthetic intelligence, and analytic domains that include musical, logical intelligence and naturalistic intelligence.

2) Criteria for interest in prospective students of mathematics education study programs that have an introspective and interactive domain including medium and high criteria. As for the analytic domain, the criteria for high interest in mathematics.

3) Interactive domains with high interest criteria solve the overall problem of Polya's steps, while Polya's problem solving stage with moderate interest criteria is not carried out as a whole, that is not going through the re-checking stage. Polya's problem solving phase from the analytic and introspective domains with moderate and high interest criteria was carried out as a whole.

\section{References}

[1] Arikunto, S.: Prosedur Penelitian Suatu Pendekatan Praktik. Rineka Cipta, Jakarta (2014)

[2] Darojat, L. \& Kartono: Kemampuan Pemecahan Masalah Siswa dalam Menyelesaikan Soal Open Ended Berdasarkan AQ dengan Learning Cycle 7E. Unnes Journal of Mathematics Education Research. Vol. 5, No. 1 (2016)

[3] Gardner, H.: Terjemahan: Multiple Intelegence (Kecerdasan Majemuk: Teori dalam Praktik). Interaksara, Jakarta (2003)

[4] In'am, A.: Menguak Penyelesaian Masalah Matematika (Analisis Pendekatan Metakognitif dan Model Polya. Aditya Media, Malang (2015)

[5] Muslihun \& Hildayani, S. Z.: SUJU: Sukses Juara Olimpiade Matematika SMA/MA Nasional dan Internasional. Grasindo, Jakarta (2015)

[6] Posamentie, AS \& Krulik, S.: Problem Solving Strategies for Efficient anad Elegant Sollution. Cormin Press.Inc, California (1988)

[7] Prawira, P.A.: Psikologi Pendidikan dalam Perspektif Baru. Ar-Ruz Media, Jogjakarta (2011)

[8] Rahbarnia, F., Hamedian, S., Radmehr, F.: A Study on the Relationship Between Multiple Intelligence and Mathematical Problem Solving Based on Revised Bloom Taxonomy. Journal of Interdisciplinary Mathematics. Vol. 17, No. 2 (2014)

[9] Rohmatin, D. N. \& Rahmawati, A.: Profil Berpikir Kritis Siswa SMP dalam Memecahkan Masalah Matematika Ditinjau dari Kecerdasan Majemuk sebagai Upaya Dasar Menentukan Strategi Pembelajaran. Indonesian Science \& Technology Digital Library. elib.pdii.lipi.go.id (2013)

[10] Sapitri, dkk.: Analisis Kemampuan Pemecahan Masalah Matematis Siswa dalam Menyelesaikan Soal Open-Ended pada Materi Lingkaran Ditinjau dari Minat Belajar. Jurnal Variabel. Vol. 2, No. 1 (2019)

[11] Slameto.: Belajar \& Faktor-faktor yang Mempengaruhi. Rineka Cipta, Jakarta (2010)

[12] Sumadi, S. Analisis Proses Pemecahan Masalah Matematika pada Siswa SMA Berdasarkan Kecerdasan Majemuk. Universitas Muhammadiyah Malang. Tesis (2016)

[13] Sumarsono.: Metode Riset Sumber Daya Manusia. PT. Graha Ilmu, Jakarta (2011)

[14] Suwartono. Dasar-Dasar Metodologi Penelitian. Andi Offset Press, Jogjakarta (2014)

[15] Wijaya, K. H. \& Sudarmin.: Kemampuan Pemecahan Masalah Matematika Siswa Kelas VIII Berdasarkan Multiple Intelligence pada Setting PBL. Unnes Journal of Mathematics Education Research. Vol. 5, No. 2 (2016)

[16] Yaumi, M. dan Ibrahim, N.: Pembelajaran Berbasis Kecerdasan Jamak (Multiple Intelligences): Mengidentifikasi dan Mengembangkan Multitalenta Anak. Kencana, Jakarta (2013) 